\title{
Aggregation of under canopy and bare soils in a Mediterranean environment affected by different fire intensities
}

\author{
J. Campo*, E. Gimeno-García, V. Andreu, O. González-Pelayo, J.L. Rubio
}

Centro de Investigaciones sobre Desertificación - CIDE (CSIC, Universitat de València, Generalitat Valenciana), Camí de la Marjal, s/n, Albal, 46470 Valencia, Spain 

(1)

\section{Aggregation of under canopy and bare soils in a Mediterranean environment} affected by different fire intensities

J. Campo*, E. Gimeno-García, V. Andreu, O. González-Pelayo, J.L. Rubio

Centro de Investigaciones sobre Desertificación - CIDE (CSIC, Universitat de València, Generalitat Valenciana), Camí de la Marjal, s/n, Albal, 46470 Valencia, Spain

\section{Abstract}

Soil macroaggregation in relation to soil organic matter (SOM) and calcium carbonate $\left(\mathrm{CaCO}_{3}\right)$ content was studied, before and after experimental fires of different intensities, in two environments (under canopy and on bare soil). In 1995, two experimental fire treatments, based on the addition of different biomass amounts, were applied on a set of nine plots at the Permanent Field Station of La Concordia (Valencia, Spain). Three plots were burned with high intensity fire (T1), three with moderate intensity (T2) and three plots were left unburned to be used as control treatment (T3). Soils under canopy were characterized by higher macroaggregate stability (SMS), SOM content and mean weight diameter of aggregates (MWD) than bare soils, which presented higher $\mathrm{CaCO}_{3}$ contents.

After the fires, tendencies to increase were observed in the SOM and SMS of all burned soils, probably because of the incorporation of partially burned plant material. The trends of SMS and SOM in T1 burned soils were towards to decrease with the occurrence of the first erosive rainfalls. These trends continued until the end of the study. MWD of under canopy soils on T1 and of soils on T2 showed a decreasing trend 
1 immediately after fire treatments. Not significant differences between sampling periods

2 were found for $\mathrm{CaCO}_{3}$ content, with the exception of under canopy soils on $\mathrm{T} 1$ which

3 tended to increase, and showed higher values at the end of the studied period. The

4 differences observed initially between under canopy and bare soil disappeared after one

5 year of fire in $\mathrm{T} 1$, which suggests a major degradation of soils affected by this 6 treatment.

$7 \quad$ Significant changes of the studied properties were not observed in unburned soils 8 during one year of research. In these soils, organic matter showed significant 9 correlations with macroaggregate stability and mean weight diameter. However, 10 significant statistical relationships were not observed between the studied properties in

11 burned soils, showing that fire impact probably affected other soil characteristics related 12 to soil aggregation.

14 Keywords: Macroaggregation, Soil Organic Matter, Calcium Carbonate, Mean Weight 15 Diameter, Experimental plots.

\section{Introduction}

Aggregate stability is one of the key characteristics of soil resistance to post-fire erosion. The most important binding agents involved in aggregation includes organic 21 matter, calcium carbonates, organo-metallic compounds, microbial mucilage, etc. 22 (Tisdall and Oades, 1982; Le Bissonnais, 1996; Boix-Fayos et al., 2001). The heating of soil by fire tends to alter these agents and, therefore, the aggregate 24 stability (Giovannini et al., 1990; Kutiel and Inbar, 1993; Andreu et al., 1996; DeBano, 


\section{2. Materials and Methods}

3

\section{$4 \quad 2.1$. Study area} 7 Field Station is located on a forested concave hillside with a SSE aspect, $22^{\circ}$ of slope 8 and an altitude around $575 \mathrm{~m}$ a.s.l. The terrain was ceded by the Forestry Services of the 9 Valencian Governement (Generalitat Valenciana).

This work was carried out at the Permanent Field Station of La Concordia, in the municipality of Lliria, $50 \mathrm{~km} \mathrm{NW}$ of Valencia City, Spain $\left(39^{\circ} 45^{\prime} \mathrm{N}\right.$ and $\left.0^{\circ} 43^{\prime} \mathrm{W}\right)$. The

Soils are classified as Rendzic Leptosol type according to the FAO-UNESCO (1988), developed on Jurassic limestones, which show variable depth, always less than $40 \mathrm{~cm}$ thick, high stoniness (45\%) and sandy loam texture.

Mean annual precipitation of the area is $400 \mathrm{~mm}$, with a maximum in autumn (51.7 $\mathrm{mm}$ in October) and a less rainy period in spring (34.1 $\mathrm{mm}$ in April). The dry period usually ranges from April or May to September, with a mean temperature of $25.8^{\circ} \mathrm{C}$. The mean annual temperature is $17.2^{\circ} \mathrm{C}$.

Vegetation cover is characterized by a Mediterranean shrubland that was developed after a wildfire occurred in 1978. The most abundant species before experimental fires were Rosmarinus officinalis, Ulex parviflorus, Quercus coccifera,

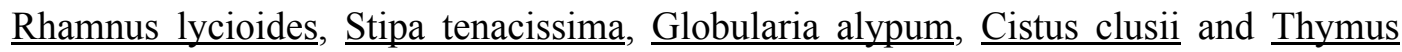
vulgaris.

The Permanent Field Station consists of a set of nine $80 \mathrm{~m}^{2}$ erosion plots, $4 \mathrm{~m}$ wide by $20 \mathrm{~m}$ long, with similar pedological and vegetation cover characteristics. The selection of each plot location was made after intensive surveys on soil, vegetation, 
1 slope angle, and surface morphology (rock outcrops and bare soil percentage) based on

258 transects transversal to the slope with a $2 \mathrm{~m}$ interval. Plots are closed, oriented 3 parallel to the slope and bounded by bricks.

4 Meteorological parameters were monitored by a logging system of sensors with

5 GSM data transmission, placed at half slope in the central part of the experimental 6 station. The rainfall parameters recorded were: total volume, rainfall intensity $\left(\underline{I}_{30}\right)$, and 7 duration of the rainfall event (D).

\section{2.2. Experimental fire design and performance}

10 In June 1995, two sets of three plots each were burned with high (T1) and 11 moderate (T2) intensity fires. The assignment of the fire treatment to each plot was 12 made at random, without blocking. To achieve these intensities, the addition of different 13 amounts of fuel load to the plots was necessary: $4 \mathrm{~kg} \mathrm{~m}^{-2}$ for $\mathrm{T} 1$ and $2 \mathrm{~kg} \mathrm{~m}^{-2}$ for $\mathrm{T} 2$.

14 Added biomass distribution also guaranteed the continuous progression of the fire front.

15 To maintain the same type of vegetation inside the plots, this biomass was taken from 16 the surrounding area. The remaining three plots were kept unburned to be used as the 17 control treatment (T3).

18 Temperatures on the soil surface were measured by means of thermocouples and 19 thermosensitive paints. With thermocouples, the residence time of temperatures on soil 20 was also measured. In this way, direct estimates were made of the duration of 21 temperatures higher than $100^{\circ} \mathrm{C}$ on the soil surface. This value was selected because 22 beyond this temperature the most relevant changes in the soil can occur (Whelan, 1995;

23 Gimeno-García et al., 2000). In each plot, six thermocouples type K Inconel 60024 insulated were installed at ground level along parallel lines running down the slope and 
1 separated from one another by $3 \mathrm{~m}$. Additionally, a set of 24 thermosensitive paints

2 (Omega Stick Crayons) ranging between $100^{\circ} \mathrm{C}$ and $677^{\circ} \mathrm{C}$ was applied on iron rods and 3 placed in each square meter of the plot to measure the maximum temperature reached.

4 Each iron rod was covered with another identical rod, not painted, to protect them from 5 ashes and flames. A total of 80 iron rods per plot were used.

6 The mean soil surface temperature reached was $439^{\circ} \mathrm{C}$ in $\mathrm{T} 1$ plots and $232^{\circ} \mathrm{C}$ in $\mathrm{T} 2$

7 plots, and temperatures higher than $100^{\circ} \mathrm{C}$ lasted 36 and 17 minutes for each treatment, 8 respectively, as noticed by Gimeno-García et al. (2004).

\subsection{Soil sampling and analysis}

11 Four samples per plot, two from soil under canopy and two from bare soil, were

12 taken from $0-5 \mathrm{~cm}$ depth (12 samples per treatment; a total of 36 samples per sampling

13 period). Samples were taken before fire, immediately after, one month, four months, 14 and one year after the fire. Samples were air-dried and screened to remove the fraction 15 higher than $2 \mathrm{~mm}$ diameter, and stored in plastic boxes until analysis.

16 Organic matter content was determined by the Walkley-Black method (Jackson, 17 1958). Total carbonates were measured using the Bernard calcimeter method (MAPA, 18 1986). The aggregate stability measured with a $0.25 \mathrm{~mm}$ diameter mesh is called 19 macroaggregate stability according to the Edward and Bremner (1967) classification 20 (microaggregates: $<0.25 \mathrm{~mm}$ and macroaggregates: $>0.25 \mathrm{~mm}$ ). To assess this soil 21 macroaggregate stability, a wet-sieving procedure was used (Primo-Yufera and 22 Carrasco, 1973).

23 The soil was hand screened, with a sieves battery, to separate it in the following 24 aggregate size fractions: $2-1 \mathrm{~mm}, 1-0.5 \mathrm{~mm}, 0.5-0.25 \mathrm{~mm}, 0.25-0.1 \mathrm{~mm}, 0.1-0.05 \mathrm{~mm}$ 
1 and $<0.05 \mathrm{~mm}$. The percentage by weight of aggregates at each fraction was used to

2 calculate the Mean Weight Diameter index (MWD) (Chaney and Swift, 1984).

3 Analysis of variance, Tukey's and t-Student's tests at $\alpha=0.05$ were performed to

4 detect differences in the studied soil characteristics. Standard statistical bivariate and

5 partial correlation analyses were applied, at 95 and 99\% significance levels, between the

6 aggregate size distribution, the macroaggregate stability and the cementing agents

$7 \quad\left(\mathrm{SOM}\right.$ and $\left.\mathrm{CaCO}_{3}\right)$.

\section{3. Results and Discussion}

\section{3.1. Soil Macroaggregate Stability (SMS)}

12 Results obtained showed that the statistically significant differences observed on

13 SMS were mainly related to the presence or absence of vegetation for all fire treatments

14 (Fig. 1). Before fires, soils under canopy presented higher SMS values ( 35\%) than bare

15 soils $(\sim 24 \%)$. The high stabilities measured in soils under canopy could be understood

16 as consequence of the incorporation of organic matter into the soil and its role as

17 cementing agent in a more protected environment (Tisdall and Oades, 1982; Schulten et

18 al., 1993; Amézketa, 1999).

19 Immediately after fires, SMS changes on both fire treatments were not statistically

20 significant respect to their pre-fire values (Table 1). Soils on T1 showed increasing

21 stabilities during the first post-fire month, but only statistically significant in those

22 under canopy (Fig. 1). Besides a possible incorporation of organic matter into bare soils,

23 the trend to increase measured in this environment could be, in part, related to a

24 hardening of soil aggregates, possibly due to changes on clay lattice layers or in iron 
1 oxides crystallinity at temperatures higher than $220^{\circ} \mathrm{C}$ (Giovannini and Lucchesi, 1997;

2 Guerrero et al., 2001). Soils of both environments on T2 presented also increasing 3 trends during the first month after fire (Fig. 1).

4 The first rain events (Table 2) occurred two months after the fire could have 5 changed the SMS tendency on T1 soils. In under canopy soils on this treatment, 6 statistically significant differences were found between the SMS values of the first 7 month and one year sampling. Aggressiveness of rain events favoured erosion on these 8 soils, as was reported by Campo et al. (2006), and possibly homogenised the SMS 9 values obtained. In this treatment, four months after the fire, differences in SMS of 10 under canopy and bare soils were not found.

11 Despite the high sediment yields measured on the T2 plots (Campo et al., 2006), 12 increasing tendency registered in the SMS of soils under canopy on this treatment 13 continued until four months after the fire. It seems that rainfalls affected in a greater 14 way soils on $\mathrm{T} 1$ than on $\mathrm{T} 2$ reflecting the lower vulnerability to degradation of $\mathrm{T} 2$ soils.

15 The moderate fire intensity and the small variation in SOM content of soils under 16 canopy on T2 after fires (Fig. 2) could have preserved the stability of these soils 17 reducing the raindrop impact effect. Temperature reached during the moderate intensity 18 fire $\left(232^{\circ} \mathrm{C}\right.$ average $)$ could have created an accumulation of hydrophobic substances in 19 soil, which could react stabilizing soil macroaggregates (Giovannini, 1994; Mataix20 Solera and Doerr, 2004).

21 Statistically significant differences in SMS were not found between under canopy 22 and bare soils on $\mathrm{T} 1$ four months after fire. On the other hand, on T2, despite the 23 decreasing tendency in the SMS of under canopy soils, statistically significant 24 differences between them and bare soils were detected during all the studied period. 
1 One year after the beginning of the research, the unburned bare soils showed very

2 low macroaggregate stability. The aggressive 1995 autumn rains, typical of the

3 Mediterranean region, could have impacted the more stable macroaggregates of these

4 soils. The absence of vegetation cover could explain the difference of $\sim 16 \%$ in the SMS

5 values found at the end of the study between both environments in the soils on this

6 treatment (Fig. 1).

7

8 3.2. Soil Organic Matter (SOM)

9 Trends observed for organic matter in the studied soils were similar to those 10 reported for macroaggregate stability. Differences in SOM contents were not 11 statistically significant between the fire treatments applied (Table 1), but they were 12 detected between environments (Fig. 2). Before fire, all soils under canopy presented 13 higher SOM contents $(\sim 12 \%)$ than bare soils $(\sim 9 \%)$. As mentioned above, these higher 14 contents in the soils of this environment seem to be the agent responsible for their 15 higher macroaggregate stability.

16 Changes in the SOM content of burned soils, immediately after the fires, were not 17 statistically significant (Table 1). Despite a slight decrease in the SOM of under canopy 18 soils on T1, soils in both environments on this treatment showed increased trends during 19 the first month (Fig. 2), suggesting a direct relation between SOM and SMS (Table 3).

20 This insignificant decrease could be related with combustion of SOM, according with 21 the results reported by Fernández et al. (1997), Mataix-Solera et al. (2002) and 22 González-Pérez et al. (2004) in Mediterranean and Atlantic soils burned with similar 23 treatment. 
1 Soils in both environments on the moderate intensity fire (T2) presented also

2 increasing SOM trends during the first month. All these increasing tendencies could be 3 due to incorporation of ashes and residual biomass partially burned into the soil

4 (Gimeno-García et al., 2000). The organic matter content measured in these ashes was

5 approximately $5 \%$ in $\mathrm{T} 1$ and $8.5 \%$ in $\mathrm{T} 2$ plots. Small changes produced by moderate

6 temperatures, especially in the aromatic recalcitrant compounds (Pardini et al., 2004),

7 could also help to explain this trend in T2 soils.

8 Torrential rainfall events fell two months after the fire (Table 2) produced high 9 sediment yields (Campo et al., 2006) and losses of SOM close to $20 \mathrm{~g} \mathrm{~m}^{-2}$ (Gimeno10 García et al., 2000). In the fourth month post-fire, soils of both environments on T1 11 showed decreasing tendencies in their SOM content, which could be directly related 12 with erosive processes.

13 Increasing SOM trend, of soils under canopy on T2 soils was still observed four 14 months after the fire, conversely to bare soils, in which it changed one month after. As 15 mentioned before, the moderate intensity fire occurred in this treatment produced ashes 16 with high organic matter content $(8.5 \%)$, and its incorporation into the soil could 17 explain this fact. High SOM content would help also to preserve the high SMS of this 18 soil, even after raindrop impact.

19 In the period between four months and one year after the fire, all burned soils 20 showed decreasing trends in their SOM contents. Soil under canopy on T1 appeared to 21 be the more degraded, losing approximately $40 \%$ of its initial SOM. In spite of this 22 tendency to decrease, statistically significant differences were only found in the SOM 23 content of bare soils on $\mathrm{T} 1$ between one month and one year after the fire. Organic 
1 matter of T2 soils did not show statistically significant differences during the whole

2 study period (Fig. 2).

3 SOM on control soils (T3) scarcely changed during the one year research period.

4 Bare soils on this treatment always presented the lowest contents (Fig. 2).

5

6 3.3. Calcium Carbonate $\left(\mathrm{CaCO}_{3}\right)$

7 The studied soils showed high calcium carbonate contents (Fig. 3). Similarly to

8 the other characteristics already described, there were not statistically significant

9 differences in the $\mathrm{CaCO}_{3}$ contents of soils between fire treatments (Table 1), but they

10 were observed between the studied environments.

11 However, the $\mathrm{CaCO}_{3}$ content presented an opposite trend to SMS and SOM

12 because higher calcium carbonate contents were observed in bare soils $(\sim 50 \%)$ than in

13 soils under canopy $(\sim 46 \%)$. In both environments, the large soil stoniness (Jurassic

14 limestones) greatly contributed to preserve these high contents because of the

15 dissolution and re-precipitation of calcite, typical of superficial soils horizons developed

16 on carbonated rocks (Duchaufour, 1984; Dutil, 1987).

17 Immediately after the fires, the little variations measured in the $\mathrm{CaCO}_{3}$ values of

18 burned soils were not statistically significant (Table 1). However, the difference in the

$19 \mathrm{CaCO}_{3}$ contents found before the fire between under canopy and bare soils disappeared

20 in both fire treatments (Fig. 3). As stated by Christensen (1973), the high content on

21 alkaline metal carbonates found in ashes deposited on soil after fires could be a source

22 of $\mathrm{CaCO}_{3}$, particularly on under canopy soils.

23 Significant changes in the $\mathrm{CaCO}_{3}$ content of studied soils were not observed

24 during the first four months, even after the early autumn rains (Table 2). 
1 Changes in the MWD of burned soils immediately after the fires were not

2 statistically significant (Fig. 4). The tendency to decrease observed in under canopy

3 soils on $\mathrm{T} 1$ could be related with the reduction in the mass percentage of aggregates

$4>0.5 \mathrm{~mm}$. Combustion of SOM produced by the high temperatures reached in this

5 treatment $\left(439^{\circ} \mathrm{C}\right.$ average $)$ could break the linkage between soil aggregates decreasing

6 the mass percentage of those of higher size.

7 On the contrary, bare soils on T1 presented an increasing tendency in their MWD

8 after fire. So, the difference in MWD between both environments on this treatment

9 became not significant one month after it (Fig. 4).

10 In bare soils burned with high intensity fire, some kind of re-aggregation occurred,

11 increasing mass percentages on large size aggregates $(>0.5 \mathrm{~mm})$. According to

12 Giovannini et al. (1990) and Molina and Sanroque (1996), re-aggregation of fine

13 particles is possible at temperatures higher than $220^{\circ} \mathrm{C}$. This is likely due to dehydration

14 of soil gels and transformations of the cementing Fe and $\mathrm{Al}$ oxides.

15 This hypothesis could also be confirmed with the results obtained by González-

16 Pelayo et al. (2006) who found, in another research developed also in the Permanent

17 Field Station of "La Concordia", that soils burned with high intensity fire showed

18 values of soil water content at $\mathrm{pF} 2$ significantly higher than those soils unburned or

19 burned with moderate intensity. These authors argued according with Ingelmo et al.

20 (2000) and Kay and VandenBygaart (2002), that water retained at $\mathrm{pF} 2$ is gravitational

21 water adhered to soil particles by cohesion and capillary forces. Thus, the soil water

22 content increase at this $\mathrm{pF}$ was probably held in the pores between sand-sized particles

23 associated with the re-aggregation of clay-sized particles. 
The moderate temperatures reached in the $\mathrm{T} 2$ treatment did not produce significant

2 changes in the MWD of soils. However, statistical significant differences between

3 environments were still observed in the soils on this treatment (Fig. 4).

$4 \quad$ Four months after the fire, aggregate size distribution of all burned soils showed

5 trends to decrease in the mass percentage of large aggregates. Differences in the MWD

6 of soils on T1 were statistically significant under canopy, and non significant for the

7 bare soils. As stated before, the presence of hardened aggregates with high

8 macroaggregate stability in these bare soils could explain this fact. MWD reduction of

$925 \%$ measured in the soils under canopy on T1 confirms their degradation (Fig. 4).

10 Significant differences in MWD between environments on this treatment were not

11 found.

12 Mean weight diameter of bare soils on T2 four months after the fire was lower

13 than before it. The tendency to decrease in the MWD of under canopy soils was still

14 noticeable, but the difference in respect of previous periods was not statistically 15 significant.

16 Erosive rains that fell in early autumn (Table 2) could be the factor responsible of

17 the trends observed in the MWD of all burned soils. These events could have caused the

18 breakdown of less stable macroaggregates, increasing the presence of those of lower

19 size (Le Bissonnais, 1996; Barthes and Roose, 2002). Imeson et al. (1992), who studied

20 the aggregation processes on a Mediterranean forest soil, suggested that unless the

21 burned soil between plants can be relatively rapidly covered, soil aggregates could

22 degrade into poorly aggregated finer material.

23 At the end of the research, the aggregate size distribution of soils under canopy on

24 T1 was similar to the distribution measured four months after the fire. The MWD of this 
After the fires impact, the SOM role as binding agent of soil macroaggregates is

2 less clear. Only in the soils burned with high fire intensity, organic matter was

3 positively correlated with macroaggregate stability.

4 A negative relationship between $\mathrm{CaCO}_{3}$ and $\mathrm{SOM}$ was found in all studied soils

5 (Table 3). Correlation analyses between $\mathrm{CaCO}_{3}$ and $\mathrm{SMS}$ showed significant negative

6 coefficients in $\mathrm{T} 3$ and $\mathrm{T} 1$ soils. As this negative correlation could be due to the

7 interaction of the negative relationship between $\mathrm{SOM}$ and $\mathrm{CaCO}_{3}$, partial correlation

8 analyses between SMS and MWD with $\mathrm{CaCO}_{3}$ controlling the effect of SOM were 9 done.

10 The partial correlation analyses confirmed that the negative relationships found 11 between SMS and $\mathrm{CaCO}_{3}$, and between MWD and $\mathrm{CaCO}_{3}$ were highly related to the 12 SOM interaction. In the table 3 can be observed that the significant correlation 13 disappeared when the partial correlation analysis is done (Pearson correlation 14 coefficients in parentheses). It seems that calcium carbonate effect in the binding of 15 macroaggregates in the studied soils, burned and unburned, is minimal.

16 In agreement with the results, organic matter content appears to drive the 17 aggregation of the unburned soils of this work. According to Boix-Fayos et al. (2001), 18 the stability of macroaggregates in soils of the Southeast of Spain is dependent of the 19 organic matter when its content is greater than 5 or $6 \%$. Below this threshold, the 20 aggregate stability is more dependent of the calcium carbonate content.

21 In this study, the binding agents responsible of the macroaggregate stabilization of 22 burned soils were not clearly identified. However, soils on T1 and T2 showed similar 23 trends in the evolution of their SMS and SOM contents, which were different to their $24 \mathrm{CaCO}_{3}$ content tendency. Thus, in burned soils with high organic matter content, this 
1 agent appears to be more important in the binding of soil macroaggregates than calcium

2 carbonate.

3

\section{4. Conclusions}

5

6 In general, before the fire, soils under canopy presented higher SOM contents,

7 MWD (aggregates $>0.5 \mathrm{~mm}$ ) and stability than bare soils. Aggregates $<0.5 \mathrm{~mm}$ were the

8 dominant fraction in bare soils, which showed lower MWD, SOM and stabilities but

9 higher calcium carbonate contents.

10 Scarce changes in the studied properties were observed immediately after the fires,

11 and they were not statistically significant. During the first month after them, organic

12 matter tended to increase in all studied soils, which can be attributed to the

13 incorporation of partially burned material with high organic matter content.

14 Under canopy, soils affected by high intensity fire showed the highest SMS one

15 month after, whereas only scarce changes on SMS and MWD were observed in bare

16 soils. In the moderate intensity treatment, both environments showed similar trends, but

17 statistical significant variations in SMS and SOM were not found. First high intensity

18 rainfalls after fire could have caused the change in the SMS and SOM tendencies of all

19 studied soils, related probably with the break down of high size aggregates as showed

20 the MWD decreasing trends.

21 The decreasing trends on MWD, SOM and SMS and the increase in $\mathrm{CaCO}_{3}$ of the

22 soils affected by the high intensity treatment provoked that, one year after the fire experiment, the statistical significant differences existing in all the studied properties 
1 between environments on this treatment disappeared, which can be interpreted as soil

2 degradation since the values in under canopy soils were always higher than in bare soils.

3 According with the results obtained, in the Mediterranean forest soils, the presence

4 of vegetation contributes to increase the soil organic matter content that, usually,

5 favours the increase in macroaggregate stability and aggregates size. Even after the

6 impact of fires of different intensities, SOM seems to be the main binding agent of soil

7 macroaggregates, and the role of $\mathrm{CaCO}_{3}$ on that could be not relevant.

\section{Acknowledgements}

10 We thank the financial support from the Agreement Generalitat Valenciana - CSIC

11 (2005020112) "Impacto de los incendios forestales repetidos sobre los procesos de

12 erosión hídrica del suelo y la recuperación de la cubierta vegetal. Seguimiento y

13 evaluación en una estación permanente de campo", and the Ministerio de Educación y

14 Ciencia of the Spanish Government project "Procesos y balances hidrológicos y de

15 sedimentos a diferentes escalas espaciales en ambientes mediterráneos: Efectos de la

16 variabilidad climática y los cambios de uso del suelo" (PROBASE CGL2006-11619).

\section{References}

19 Amézketa, E., 1999. Soil aggregate stability: A review [Review]. Journal of Sustainable $20 \quad$ Agriculture, 14 (2-3): 83-151.

21 Andreu, V., Rubio, J.L., Forteza, J., Cerni, R., 1996. Postfire effects on soil properties 22 and nutrient losses. International Journal of Wildland Fire, 6 (2): 53-58. 
1 Ketterings, Q.M. and Bigham, J.M., 2000. Soil color as an indicator of slash-and-burn

2 fire severity and soil fertility in Sumatra, Indonesia. Soil Science Society of

3 American Journal, 64 (5): 1826-1833.

4 Kutiel, P. and Inbar, M., 1993. Fire impacts on soil nutrients and soil erosion in a

5 Mediterranean pine forest plantation. Catena, 20: 129-139.

6 Le Bissonnais, Y., 1996. Aggregate stability and assessment of soil crustability and

7 erodibility: I. Theory and methodology. European Journal of Soil Science, 47 (4):

$8 \quad 425-437$.

9 MAPA, 1986. Métodos oficiales de análisis (suelos). Ministerio de Agricultura, Pesca y 10 Alimentación, Madrid.

11 Mataix-Solera, J. and Doerr, S.H., 2004. Hydrophobicity and aggregate stability in 12 calcareous topsoils from fire-affected pine forests in southeastern Spain. Geoderma, $13 \quad 118(1-2): 77-88$.

14 Mataix-Solera, J., Gómez, I., Navarro-Pedreno, J., Guerrero, C. and Moral,R., 2002.

15 Soil organic matter and aggregates affected by wildfire in a Pinus halepensis forest in 16 a Mediterranean environment. International Journal of Wildland Fire, 11 (2): 107$17 \quad 114$.

18 Molina, M.J. and Sanroque, P., 1996. Impact of forest fires on desertification processes:

19 a review in relation to soil erodibility. In: J.L. Rubio and A. Calvo-Cases (Editors),

20 Soil degradation and desertification in Mediterranean environments. Geoforma 21 Ediciones, Logroño, pp. 145-163.

22 Pardini, G., Gispert, M., Dunjo, G., 2004. Relative influence of wildfire on soil 23 properties and erosion processes in different Mediterranean environments in NE 24 Spain. Science of the Total Environment, 328 (1-3): 237-246. 
(T1)



(T2)

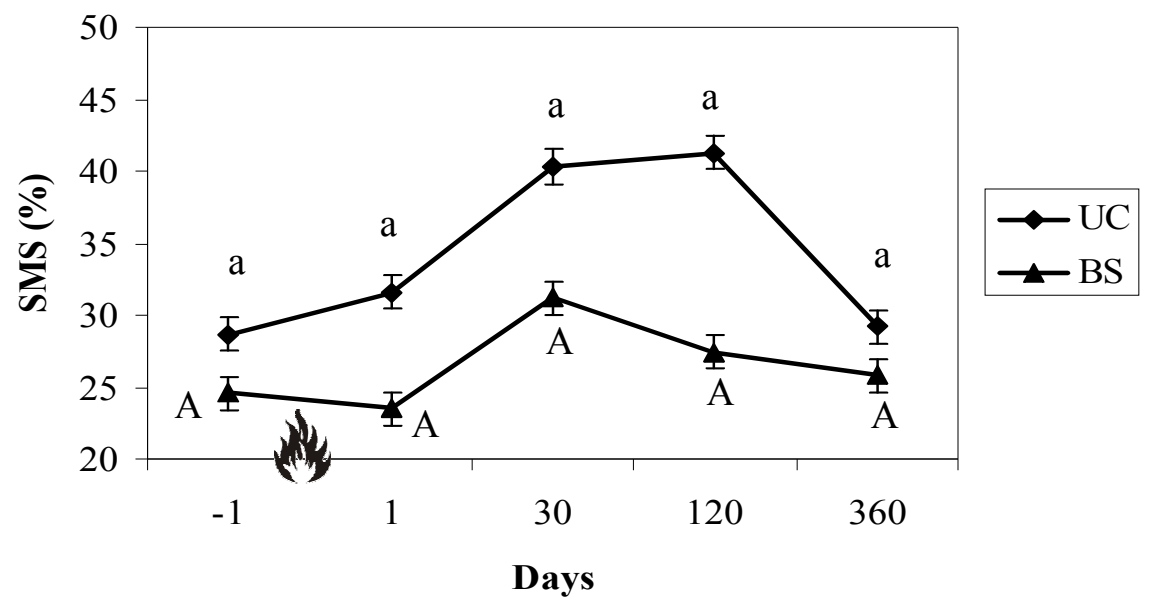

(T3)

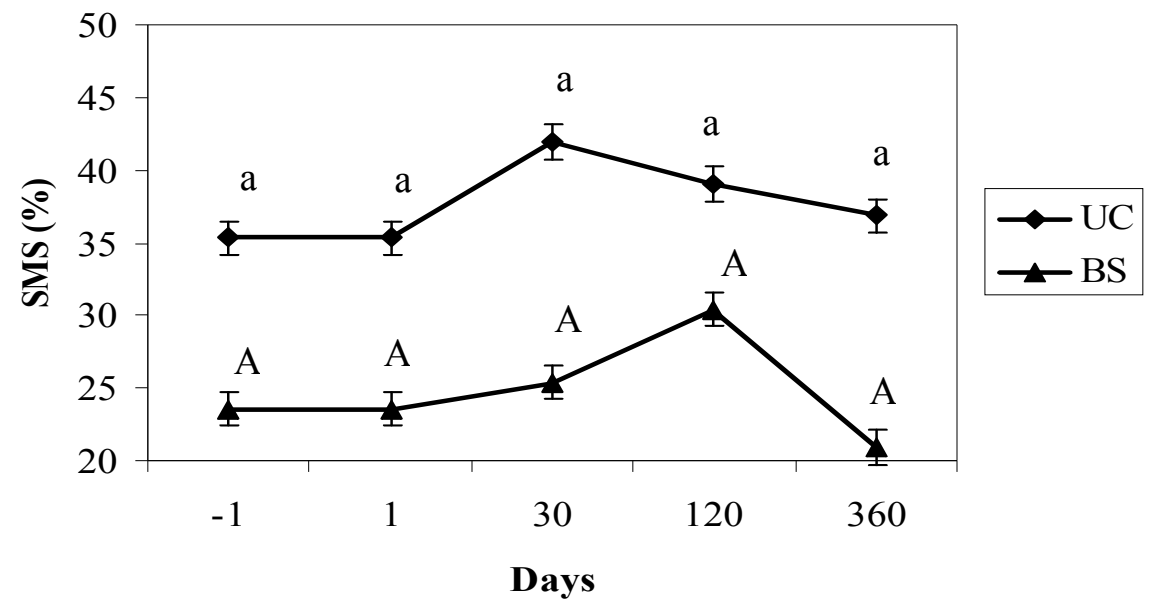

Fig. 1. Mean Soil Macroaggregate Stability (SMS) for under canopy soil (UC) and bare soil (BS) by treatment: (T1) high fire intensity, (T2) moderate fire intensity and (T3) unburned. Standard errors in bars show significant differences between environments. Different letters indicate significant differences between each studied period (lower case letters are used for under canopy soil data and upper case letters for bare soil data). Time in days is measured respect to the day of the experimental fire 
(T1)

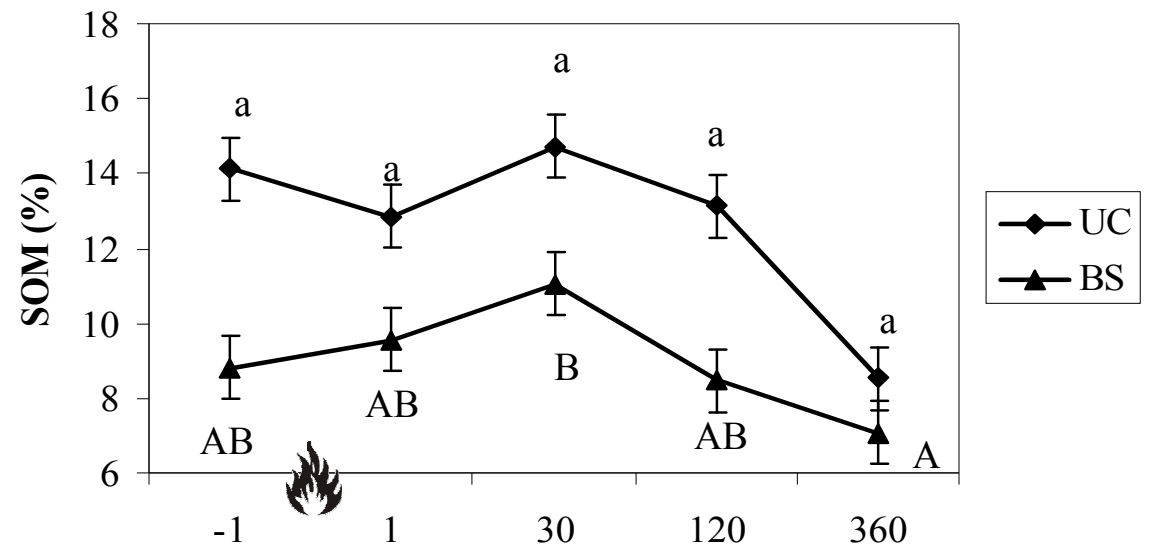

(T2)

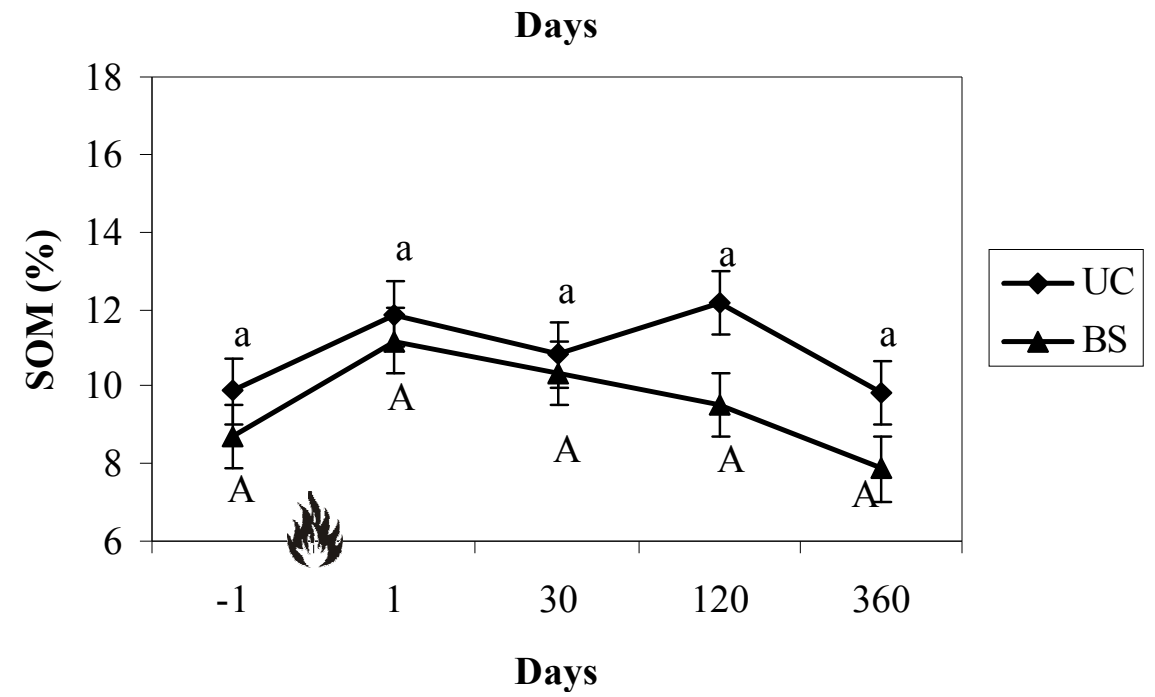

(T3)

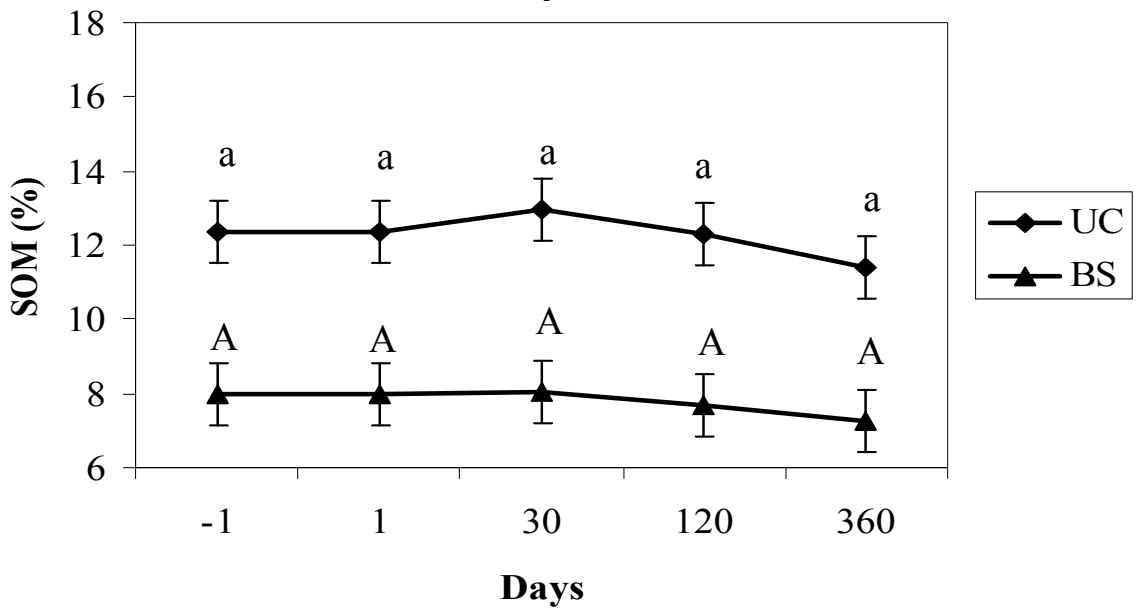

Fig. 2. Mean Soil Organic Matter (SOM) for under canopy soil (UC) and bare soil (BS) by treatment: (T1) high fire intensity, (T2) moderate fire intensity and (T3) unburned. Standard errors in bars show significant differences between environments. Different letters indicate significant differences between each studied period (lower case letters are used for under canopy soil data and upper case letters for bare soil data). Time in days is measured respect to the day of the experimental fire 
(T1)

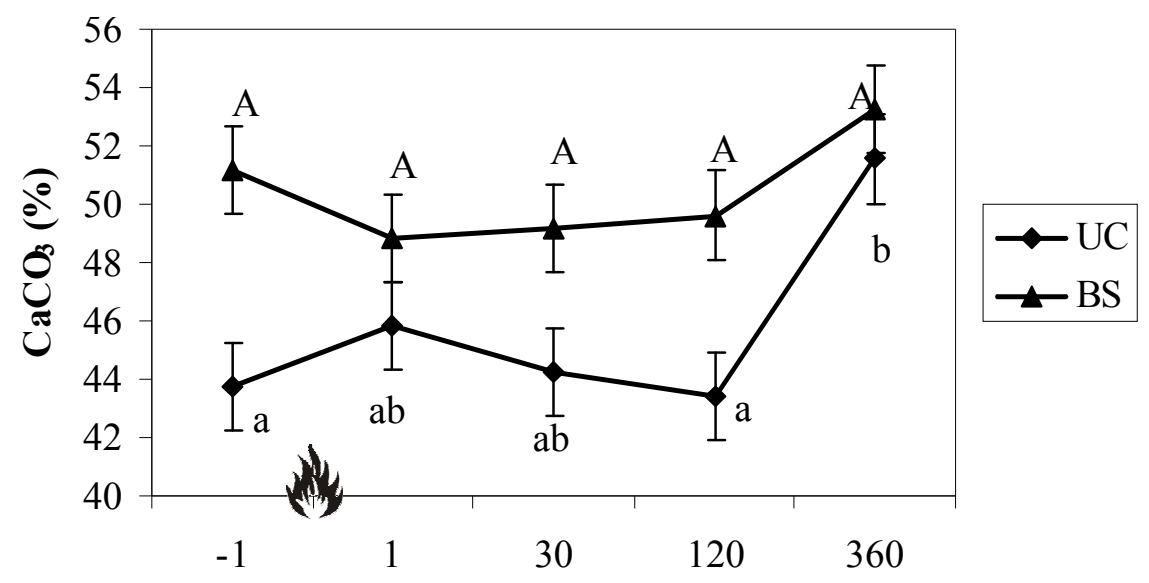

(T2)

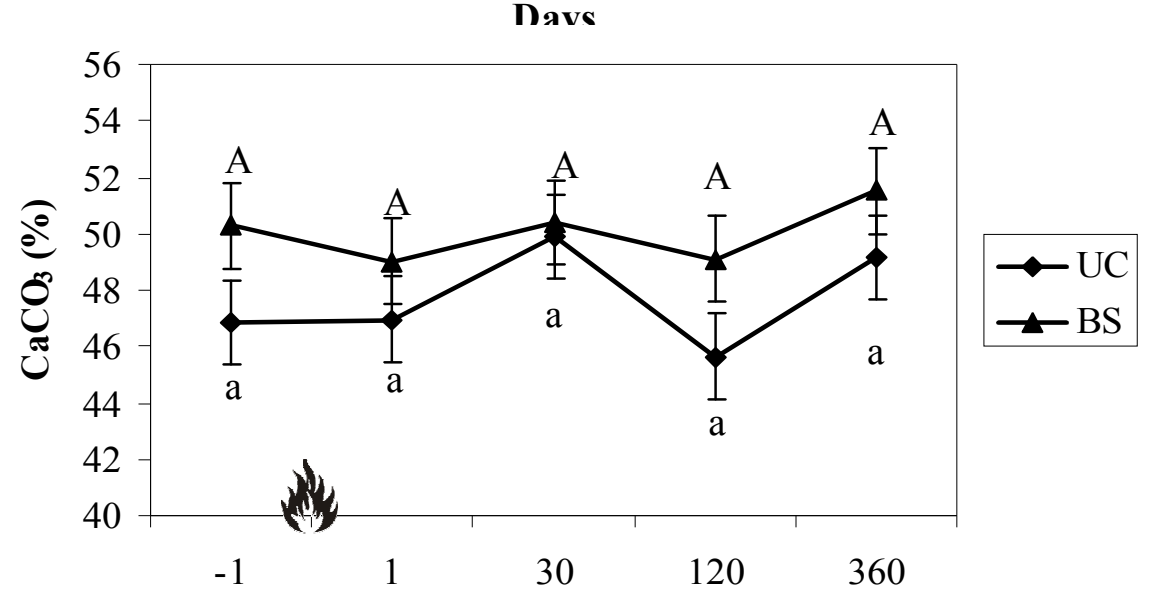

(T3)

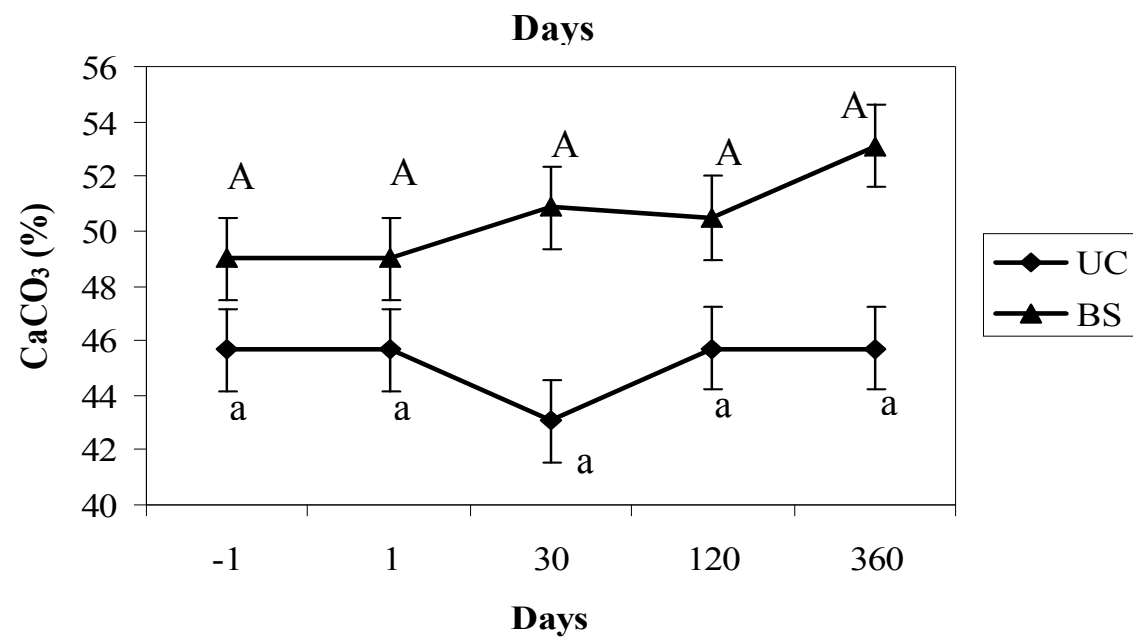

Fig. 3. Mean Calcium Carbonate Content $\left(\mathrm{CaCO}_{3}\right)$ for under canopy soil (UC) and bare soil (BS) by treatment: (T1) high fire intensity, (T2) moderate fire intensity and (T3) unburned. Standard errors in bars show significant differences between environments. Different letters indicate significant differences between each studied period (lower case letters are used for under canopy soil data and upper case letters for bare soil data). Time in days is measured respect to the day of the experimental fire 
(T1)



(T2)



(T3)



Fig. 4. Mean Weight Diameter (MWD) for under canopy soil (UC) and bare soil (BS) by treatment: (T1) high fire intensity, (T2) moderate fire intensity and (T3) unburned. Standard errors in bars show significant differences between environments. Different letters indicate significant differences between each studied period (lower case letters are used for under canopy soil data and upper case letters for bare soil data). Time in days is measured respect to the day of the experimental fire 
Table 1. Mean values of soil macroaggregate stability (SMS), soil organic matter (SOM), and calcium carbonate $\left(\mathrm{CaCO}_{3}\right)$ in high (T1) and moderate (T2) fire intensity treatments, and in unburned soils (T3). $n=12$ samples per treatment

\begin{tabular}{|c|c|c|c|c|}
\hline & Time $^{1}$ (days) & $\mathrm{T} 1$ & $\mathrm{~T} 2$ & T3 \\
\hline \multirow{5}{*}{ SMS (\%) } & -1 & $27.38^{\mathrm{a}}$ & $26.62^{a}$ & $29.43^{\mathrm{a}}$ \\
\hline & 1 & $30.91^{\mathrm{a}}$ & $27.53^{\mathrm{a}}$ & $29.43^{\mathrm{a}}$ \\
\hline & 30 & $37.55^{\mathrm{a}}$ & $35.76^{\mathrm{a}}$ & $33.66^{\mathrm{a}}$ \\
\hline & 120 & $31.95^{\mathrm{a}}$ & $34.36^{\mathrm{a}}$ & $33.88^{\mathrm{a}}$ \\
\hline & 360 & $26.01^{\mathrm{a}}$ & $27.84^{\mathrm{a}}$ & $28.90^{\mathrm{a}}$ \\
\hline \multirow{5}{*}{$\operatorname{SOM}(\%)$} & -1 & $11.47^{\mathrm{a}}$ & $9.29^{\mathrm{a}}$ & $10.15^{\mathrm{a}}$ \\
\hline & 1 & $11.22^{\mathrm{a}}$ & $11.52^{\mathrm{a}}$ & $10.15^{\mathrm{a}}$ \\
\hline & 30 & $12.90^{\mathrm{a}}$ & $10.57^{\mathrm{a}}$ & $10.51^{\mathrm{a}}$ \\
\hline & 120 & $10.81^{\mathrm{a}}$ & $10.84^{\mathrm{a}}$ & $10.00^{\mathrm{a}}$ \\
\hline & 360 & $7.80^{\mathrm{a}}$ & $8.85^{\mathrm{a}}$ & $9.32^{\mathrm{a}}$ \\
\hline \multirow{5}{*}{$\mathrm{CaCO}_{3}(\%)$} & -1 & $47.47^{\mathrm{a}}$ & $48.56^{\mathrm{a}}$ & $47.33^{\mathrm{a}}$ \\
\hline & 1 & $47.34^{\mathrm{a}}$ & $47.98^{\mathrm{a}}$ & $47.33^{\mathrm{a}}$ \\
\hline & 30 & $46.71^{\mathrm{a}}$ & $50.15^{\mathrm{a}}$ & $46.96^{\mathrm{a}}$ \\
\hline & 120 & $46.51^{\mathrm{a}}$ & $47.37^{\mathrm{a}}$ & $48.10^{\mathrm{a}}$ \\
\hline & 360 & $52.39^{\mathrm{a}}$ & $50.34^{\mathrm{a}}$ & $49.41^{\mathrm{a}}$ \\
\hline \multirow{4}{*}{ MWD (mm) } & -1 & $0.78^{\mathrm{a}}$ & $0.82^{\mathrm{a}}$ & $0.76^{\mathrm{a}}$ \\
\hline & 30 & $0.76^{\mathrm{a}}$ & $0.82^{\mathrm{a}}$ & $0.77^{\mathrm{a}}$ \\
\hline & 120 & $0.67^{\mathrm{a}}$ & $0.70^{b}$ & $0.80^{\mathrm{a}}$ \\
\hline & 360 & $0.64^{\mathrm{a}}$ & $0.66^{\mathrm{b}}$ & $0.69^{\mathrm{a}}$ \\
\hline
\end{tabular}

${ }^{1}$ Time in days is measured from the day of the experimental fire

${ }^{\mathrm{a}, \mathrm{b}}$ Values with the same superscript letter indicate no statistically significant differences between fire treatments detected by Tukey's test $(\mathrm{p}<0.05)$, in each studied period 
Table 2. Erosive rain events occurred after the 1995 fire at the Permanent Field Station of La Concordia

\begin{tabular}{ccccc}
\hline Date & $\begin{array}{c}\text { Days after } \\
\text { fires }\end{array}$ & Rain $(\mathrm{mm})$ & $\begin{array}{c}\text { Duration } \\
\text { (minutes) }\end{array}$ & $\mathrm{I}_{30}\left(\mathrm{~mm} \mathrm{~h}^{-1}\right)$ \\
\hline 23 August & 64 & 26.26 & 90 & 20.80 \\
31 August & 72 & 9.36 & 285 & 14.56 \\
18 September & 90 & 7.54 & 135 & 10.92 \\
18 September & 90 & 18.72 & 95 & 35.36 \\
4 October & 106 & 22.62 & 280 & 22.40 \\
11 November & 144 & 4.42 & 240 & 1.60 \\
25 November & 158 & 2.60 & 30 & 5.20 \\
29 November & 162 & 3.38 & 75 & 4.16 \\
\hline
\end{tabular}


Table 3. Pearson's correlation coefficients obtained between soil organic matter (SOM), calcium carbonate $\left(\mathrm{CaCO}_{3}\right)$, soil macroaggregate stability (SMS), mean weight diameter (MWD), in high (T1) and moderate (T2) fire intensity treatments and in unburned soils (T3). $n=12$ samples per treatment in each sampling period. Partial correlation coefficients obtained between $\mathrm{CaCO}_{3}$, SMS and MWD with SOM as control variable are shown in parentheses

\begin{tabular}{|c|c|c|c|c|c|}
\hline & & SOM & $\mathrm{CaCO}_{3}$ & SMS & MWD \\
\hline \multirow{4}{*}{$\mathrm{T} 1$} & SOM & 1 & & & \\
\hline & $\mathrm{CaCO}_{3}$ & $-0.62 * *$ & 1 & & \\
\hline & SMS & $0.50^{*}$ & $-0.51 *(-0.30)$ & 1 & \\
\hline & MWD & 0.24 & $-0.39(-0.33)$ & $0.67 * *$ & 1 \\
\hline \multirow{4}{*}{$\mathrm{T} 2$} & SOM & 1 & & & \\
\hline & $\mathrm{CaCO}_{3}$ & $-0.60 * *$ & 1 & & \\
\hline & SMS & 0.21 & $-0.26(-0.16)$ & 1 & \\
\hline & MWD & 0.37 & $-0.03(0.23)$ & $0.71 * *$ & 1 \\
\hline \multirow{4}{*}{$\mathrm{T} 3$} & SOM & 1 & & & \\
\hline & $\mathrm{CaCO}_{3}$ & $-0.76^{* *}$ & 1 & & \\
\hline & SMS & $0.75^{* *}$ & $-0.69 * *(-0.27)$ & 1 & \\
\hline & MWD & $0.60 * *$ & $-0.59 * *(-0.32)$ & $0.71 * *$ & 1 \\
\hline
\end{tabular}

** Significant correlation at $\mathrm{p}<0.01$

* Significant correlation at $\mathrm{p}<0.05$ 